\title{
Syncytial fusion of human trophoblast depends on caspase 8
}

\author{
S Black ${ }^{1}$, M Kadyrov ${ }^{1}$, P Kaufmann ${ }^{1}$, B Ugele ${ }^{2}$, N Emans ${ }^{3}$ and \\ B Huppertz ${ }^{\star, 1}$ \\ 1 Department of Anatomy, University Hospital Aachen, Germany; \\ 2 1. Frauenklinik-Innenstadt, University Hospital Munich, Germany; \\ ${ }^{3}$ Department of Chemistry, RWTH Aachen, Germany \\ * Corresponding author: B Huppertz, Department of Anatomy, University \\ Hospital, RWTH Aachen, Wendlingweg 2, Aachen D-52057, Germany. \\ Tel: + 49-241-8089-975; Fax: + 49-241-8082-472; \\ E-mail: bhuppertz@ukaachen.de
}

Received 20.1.03; revised 13.6.03; accepted 27.6.03; published online 12.9.03 Edited by J Tilly

\begin{abstract}
Differentiation of human placental villous trophoblast includes syncytial fusion of cytotrophoblast forming syncytiotrophoblast. Early stages of the apoptosis cascade were described to be involved in this differentiation process. We investigated the role of the initiator caspase 8 in syncytial fusion in vitro, cultivating placental villous explants with or without caspase 8 antisense oligonucleotides or peptide inhibitors for up to $120 \mathrm{~h}$. Trophoblast fusion and differentiation were assessed by confocal microscopy, immunohistochemistry and Western blot analysis. Culture with caspase 8 antisense oligonucleotides or peptide inhibitors reduced the fusion of cytotrophoblast with the syncytiotrophoblast, and resulted in multilayered cytotrophoblast. Caspase 8 expression was suppressed by antisense oligonucleotides and caspase 8 activities were reduced by peptide inhibitors. The organic anion-transporter hOAT-4 normally expressed in the cytotrophoblast and transferred into the syncytiotrophoblast by syncytial fusion was retained in the cytotrophoblast due to lack of fusion. We conclude that expression and activity of caspase 8 is a prerequisite for differentiation and syncytial fusion of cytotrophoblast cells.

Cell Death and Differentiation (2004) 11, 90-98. doi:10.1038/ sj.cdd. 4401307

Published online 12 September 2003
\end{abstract}

Keywords: apoptosis; differentiation; syncytial fusion; villous trophoblast; human placenta; caspase 8

Abbreviations: $A D A M$, a disintegrin and a metalloproteinase domain; C3, caspase 3; C8, caspase 8; CT, cytotrophoblast; DEVD, amino acids aspartic acid-glutamic acid-valine-aspartic acid; DISC, death-inducing signalling complex; FADD, Fasassociated death domain; HIV-Env, human immunodeficiency virus-envelope protein; hOAT-4, human organic anion transporter 4; IETD, amino acids isoleucine-glutamic acid-threonine-aspartic acid; PCNA, proliferative cell nuclear antigen; PS, phosphatidylserine; ST, syncytiotrophoblast; TRADD, TNF receptor-associated death domain

\section{Introduction}

Villous trophoblast of the human placenta is the transport barrier between mother and foetus. The syncytiotrophoblast as the outer part of this epithelial layer is in direct contact with maternal blood. This true syncytial layer does not show DNA synthesis, but is rather maintained by continuous fusion of the underlying mononucleated cytotrophoblast cells. The latter cells proliferate, leave the cell cycle and start to differentiate, finally fusing with the syncytiotrophoblast (for an overview, see Benirschke and Kaufmann ${ }^{1}$ ).

One accepted mechanism to initiate apoptosis is binding of a death-inducing ligand to its cognate receptor. Binding of TNF $\alpha^{2}$ or FasL ${ }^{3}$ (Apo-1L, ${ }^{4}$ CD95L) to their respective death receptors TNF-receptor 1 and Fas (Apo-1, CD95) leads to clustering of the receptors, and subsequently to the formation of the death-inducing signalling complex (DISC). ${ }^{5}$ Binding of receptor-associated proteins such as FADD or TRADD (Fas or TNF receptor-associated death domain) initiates distinct pathways to start the caspase-dependent cascade of apoptosis. Caspases are present as inactive proforms in most cells, and only the activation of caspases leads to apoptotic death of the cell. The initiator caspases such as caspase 8 are directly activated by the DISC complex, ${ }^{6}$ and are active during the early and still reversible stages of the apoptosis cascade.

In trophoblast cells, TNF $\alpha$ has been shown to induce apoptosis in vitro, ${ }^{7}$ and Phillips et al. ${ }^{8}$ have demonstrated the expression of a large number of different death receptors in trophoblast. It has been shown that during differentiation, the cytotrophoblast cells start to express antiapoptotic proteins such as $\mathrm{Bcl}-2$ and $\mathrm{Mcl}-1,{ }^{9-11}$ as well as proapoptotic caspases. ${ }^{10,12,13}$ The effector caspases 3 and 6 are inactive in the cytotrophoblast, while the initiator caspases, for example, caspase 8 , are active in the differentiating stem cells. ${ }^{10,12}$

Recent reports revealed that caspases normally known to have key functions in apoptosis are also involved in differentiation processes. These reports suggested that at least part of the enzymatic machinery of the apoptosis cascade is engaged in normal differentiation: caspase 3 has been shown to be essential in lens fibre differentiation ${ }^{14}$ and in terminal differentiation of erythroid cells. ${ }^{15}$ Caspase $3^{16}$ and caspase $14^{17-19}$ have been described to be crucial for normal epidermal differentiation of keratinocytes.

Based on our immunohistochemical and biochemical data, ${ }^{10,12}$ we hypothesize that the activity of caspase 8 is a prerequisite for the differentiation of human villous cytotrophoblast, leading to syncytial fusion with the syncytiotrophoblast. So far, only indirect proof for this hypothesis has been presented. We have shown that caspase 8 becomes activated prior to syncytial fusion. ${ }^{12}$ Initiator caspase-mediated cleavage of the caspase 8 substrate alpha-fodrin and externalization of phosphatidylserine from the inner to the outer leaflet of the plasma membrane occur early during apoptosis, ${ }^{20,21}$ and are known to be prerequisites for syncytial fusion. ${ }^{22,23}$ Highly 
differentiated cytotrophoblast displays fodrin cleavage and externalization of phosphatidylserine prior to syncytial fusion. ${ }^{12,22,23}$ Both events have been described in a variety of nonfusing cells (fodrin cleavage in, for example, neurons, oligodendrocytes, cardiomyocytes, salivary gland cells and mature red blood cells ${ }^{24-28}$ ). Thus, in the villous trophoblast, these events may act as prerequisites for fusion, with the need for other cell type-specific molecules to be directly involved in the fusion process of trophoblast.

Here we studied the role of caspase 8 in cytotrophoblast fusion in cultured placental tissue. Antisense oligonucleotides against caspase 8 and peptide inhibitors against the active caspase 8 protein were utilized to test the hypothesis that expression and activity of caspase 8 are required for villous cytotrophoblast fusion. Our data demonstrate that the downregulation of caspase 8 protein expression as well as the inhibition of caspase 8 protein activity reduce the level of syncytial fusion, and result in an accumulation of multilayered mononucleated cytotrophoblast rather than a functional syncytial layer.

\section{Results}

\section{Antisense oligonucleotides}

Control incubations of third trimester villous explants with unspecific FITC-labelled oligonucleotides revealed the distribution of labelled oligonucleotides within the trophoblast layer already after $1 \mathrm{~h}$ incubation. By phase-contrast microscopy as well as confocal microscopy, the FITC signal was prominent in the villous cytotrophoblast rather than in the syncytiotrophoblast (Figure 1).

After $48 \mathrm{~h}$ culture in the presence of antisense oligonucleotides against caspase 8 , the monolayer of cytotrophoblast became partly multilayered. Immunohistochemistry with an antibody against cytokeratin 7 revealed multiple areas per villous cross-section, where the normal cytotrophoblast monolayer of first trimester placental villi was replaced by 3-5 layers of cytotrophoblast (Figure 2).

Western blot analysis of caspase 8 revealed reduced expression of caspase 8 protein in the presence of antisense

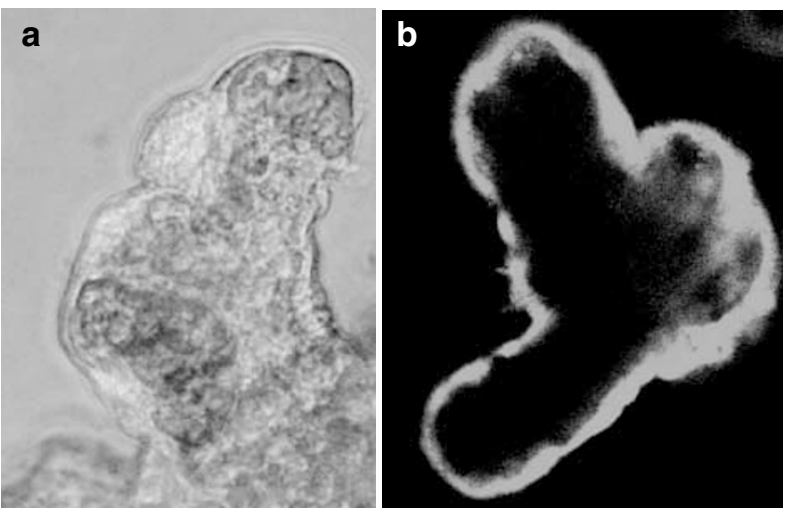

Figure 1 Incubation of explants with unspecific FITC-labelled oligonucleotides. After $1 \mathrm{~h}$ incubation, the oligonucleotides were found throughout the trophoblast layer. In phase contrast microscopy (a) and in confocal microscopy (b), the FITC signal is strong in the villous cytotrophoblast, but only weak in villous stroma at that time point $(\times 200)$
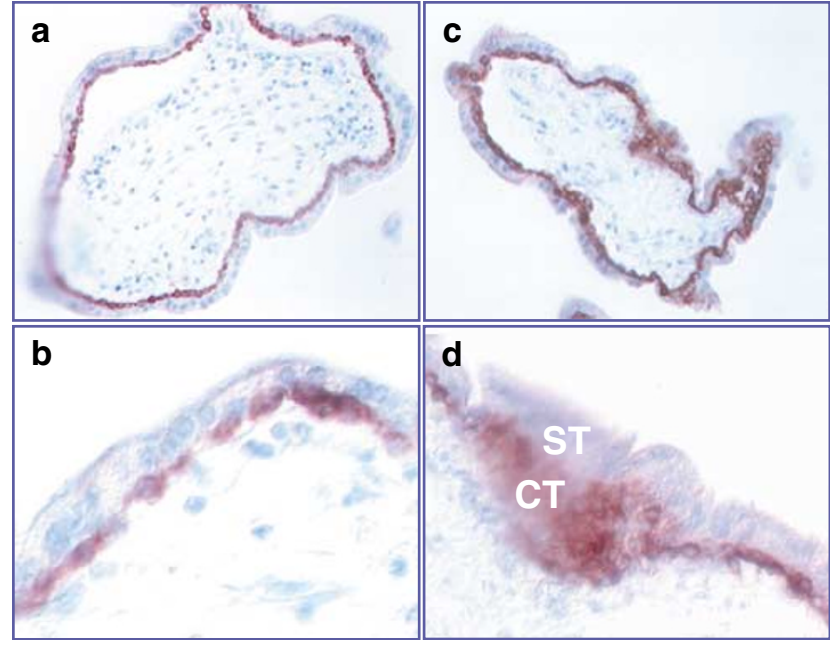

Figure 2 Immunohistochemistry with a cytokeratin 7 antibody as a marker for villous cytotrophoblast. Note the focal increase in villous cytotrophoblast following $48 \mathrm{~h}$ incubation with caspase 8 antisense oligonucleotides (c, d), as compared to controls after $48 \mathrm{~h} \mathrm{(a,b).} \mathrm{ST,} \mathrm{syncytiotrophoblast;} \mathrm{CT,} \mathrm{cytotrophoblast;} \mathrm{(a,} \mathrm{c)}$ $\times 400 ;(b, d) \times 960$

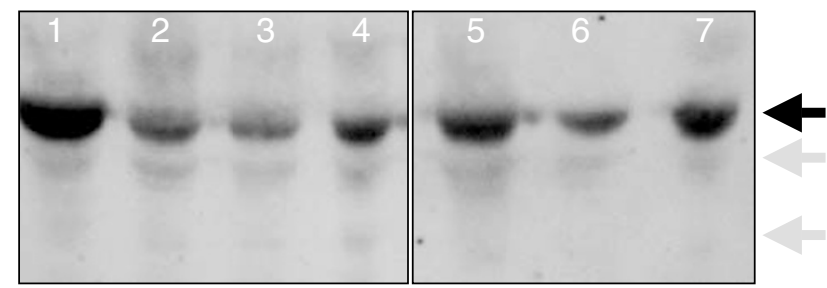

Figure 3 Western blots for caspase 8 after incubation for $48 \mathrm{~h}$ of explants from two different first trimester placentas with unspecific oligonucleotides (lanes 1,5), antisense oligonucleotides against caspase 3 (lanes 4, 7) and antisense oligonucleotides against caspases 8 (lanes $2,3,6$ ). Note the reduction of proform and active forms of caspase 8 in lanes 2, 3 and 6 as compared to controls in lanes $1,4,5$ and 7 . Black arrow, inactive proform; grey arrows, active forms

oligonucleotides against caspase 8 after cultures for $48 \mathrm{~h}$ (Figure 3) and $120 \mathrm{~h}$ (Figure 4a, b). By contrast, incubation with unspecific oligonucleotides or with antisense oligonucleotides against caspase 3 for $48 \mathrm{~h}$ did not change the expression level of caspase 8 , and thus confirmed specificity of the oligonucleotides (Figure 3). The long-term culture of villous explants $(120 \mathrm{~h})$ in the presence of antisense oligonucleotides against caspase 8 leads to a significant downregulation of the caspase 8 proform (Bonferroni: caspase 8 antisense oligonucleotides versus control, $P<0.05 ; n=3$; Figure 4c). Immunohistochemistry with an antibody against cytokeratin 7 revealed a clearly multilayered appearance of cytotrophoblast only in the presence of caspase 8 antisense oligonucleotides (Figure 4d, e).

\section{Peptide inhibitors}

Prior to culture, the villi presented the normal monolayer of cytotrophoblast (Figure 5a). After $48 \mathrm{~h}$ culture in control medium (Figure $5 \mathrm{~b}$ ) and in the presence of peptide inhibitors against caspase 3 , the monolayer still exists (Figure 5c). After $48 \mathrm{~h}$ culture with peptide inhibitors against caspase 8 , the 

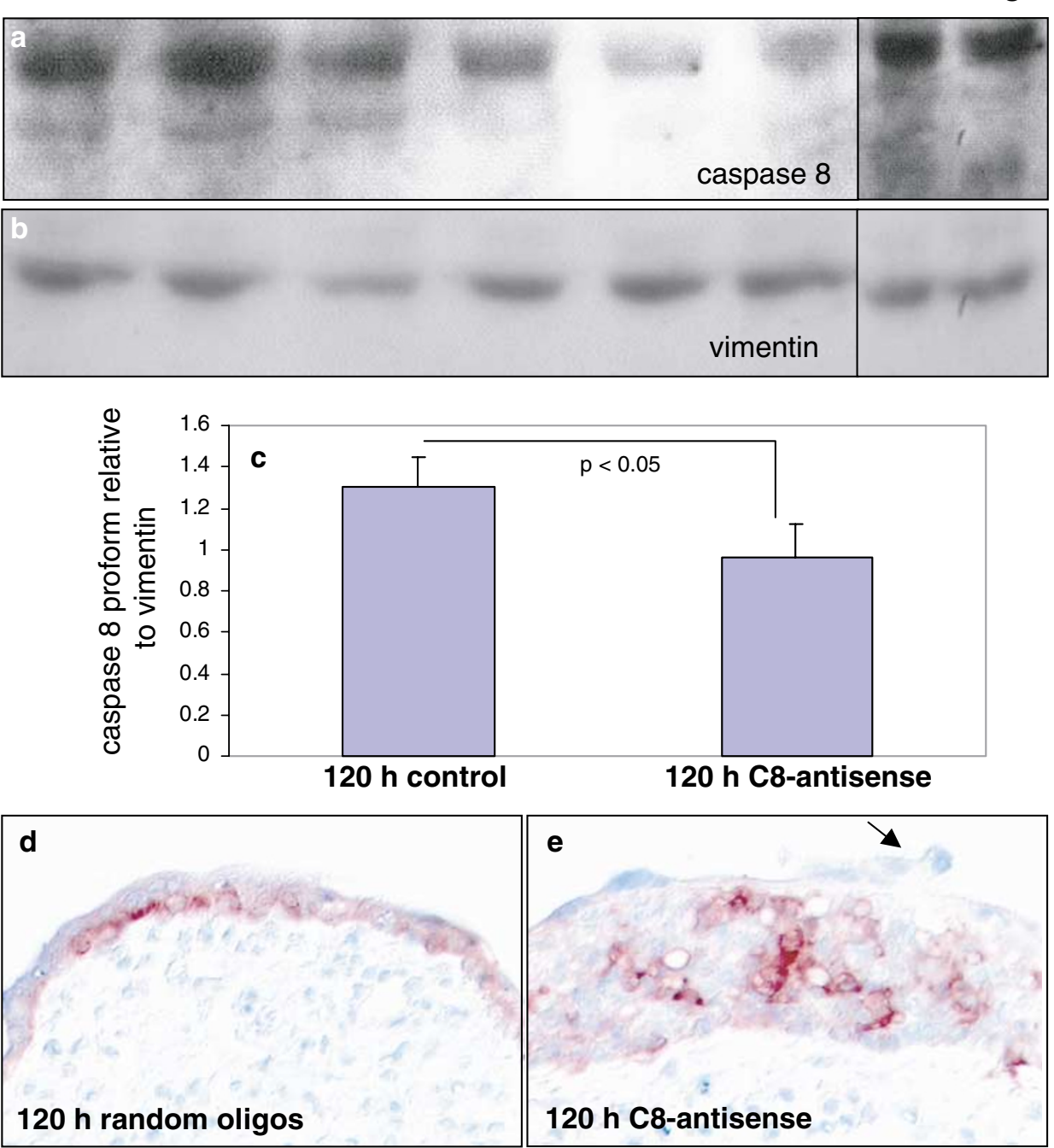

Figure 4 Villous explants were cultured in normal medium ( $120 \mathrm{~h}$ control; three different placentas) in the presence of caspase 8 antisense oligonucleotides (120 $\mathrm{h}$ C8antisense; three different placentas) or in the presence of random control oligonucleotides (120 h random oligos; two different placentas). (a) Western blot for caspase 8 , (b) Western blot for vimentin as an internal control. In (c), the densitometry of the caspase 8 proform was related to the densitometry of vimentin. A significant decrease in the expression of caspase 8 proforms was found in the presence of caspase 8 antisense oligonucleotides compared to control conditions $(P<0.05 ; n=3)$. (d) Immunohistochemistry with an anti-cytokeratin 7 antibody revealed the normal monolayered appearance of cytotrophoblast after $120 \mathrm{~h}$ culture in the presence of random oligonucleotides. (e) In the presence of caspase 8 antisense oligonucleotides, the cytotrophoblast becomes multilayered and the syncytiotrophoblast is thinning and detaches from the cytotrophoblast (arrow); (d, e): $\times 960$

cytotrophoblast layer becomes multilayered (Figure $5 \mathrm{~d}-\mathrm{f}$ ). The multilayered appearance is clearly displayed by immunohistochemistry with an antibody against a human organic anion transporter (hOAT- ${ }^{29}$ ) (Figure $5 c-f$ ). The hOAT-4 protein is normally only expressed in the syncytiotrophoblast. After $48 \mathrm{~h}$ culture in the presence of caspase 8 inhibitors, hOAT-4 is expressed only in the stratified cytotrophoblast.

To further test the failure of fusion in the presence of caspase 8 inhibitors, explants were preincubated with FITClabelled random oligonucleotides, and then further cultured in the presence or absence of caspase 8 inhibitors. Directly after incubation, the FITC-labelled oligonucleotides can be found predominantly in the nuclei of cytotrophoblast cells, while the syncytial nuclei are unstained (Figure 6a). After $24 \mathrm{~h}$ culture in the absence of inhibitors, the labelled nuclei are now found in the syncytiotrophoblast (Figure 6b). After $24 \mathrm{~h}$ culture in the presence of caspase 8 inhibitors, the labelled nuclei remain within the cytotrophoblast layer, while the syncytiotrophoblast nuclei mostly remain unstained (Figure 6c).

Quantitative analysis of cytotrophoblast cells revealed a significant increase in the number of cytokeratin 7-stained cells only in the presence of peptide inhibitors against caspase 8 compared to all other conditions (analysis of variance (ANOVA): $P<0.05$; Bonferroni: caspase 8 inhibitor versus normal medium, $P<0.05$ ) (Figure 7a).

Western blot analysis of caspase 8 revealed a significant reduction of the active forms of caspase 8 compared to control cultures without inhibitors after $24 \mathrm{~h}$ of culture (Figure $8 \mathrm{a}$ ). Further downstream of caspase 8 , cytokeratin 18 is cleaved by activated effector caspases, ${ }^{30,31}$ the latter being activated 


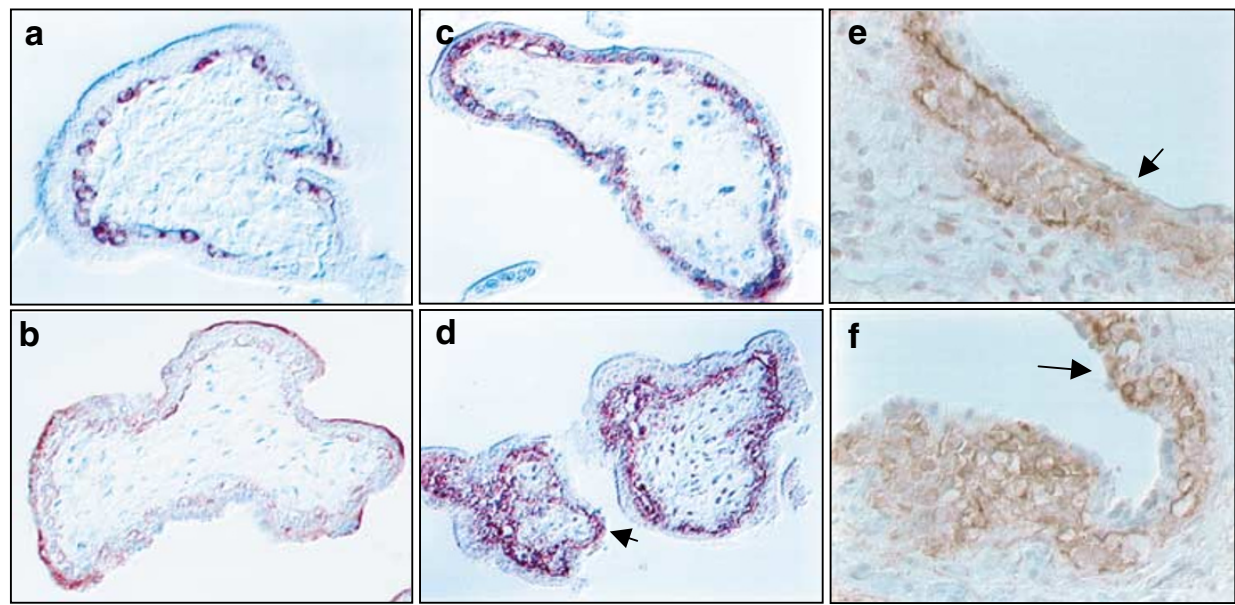

Figure 5 Immunohistochemisty for cytokeratin 7 (a), cytokeratin 18 (b) and hOAT-4 (c-f). Prior to culture the villi present the typical monolayer of cytotrophoblast (a) that remains after $48 \mathrm{~h}$ culture without inhibitors (b) or with caspase 3 inhibitors (c). Only explant cultures in the presence of peptide inhibitors against caspase 8 result in a multilayered arrangement of cytotrophoblast $(\mathbf{d}-\mathbf{f})$, suggesting the absence of syncytial fusion. arrows, focal loss of syncytiotrophoblast due to failure of syncytial fusion. $(\mathbf{a}-\mathbf{c}), \times 400 ; d, \times 200 ;(\mathbf{e}-\mathbf{f}), \times 960$

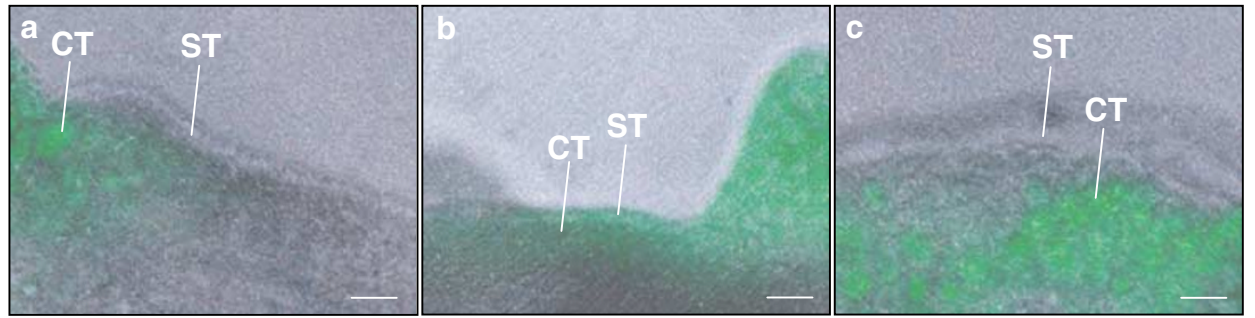

Figure 6 Villous explants were pre-incubated with $20 \mu \mathrm{M}$ FITC-labelled random oligonucleotides for $90 \mathrm{~min}$, washed and cultured for $24 \mathrm{~h}$ in the presence or absence of caspase 8 inhibitors. (a) Directly after pre-incubation the FITC-labelled oligonucleotides are present in the cytotrophoblast nuclei while the syncytial nuclei are unstained. (b) After $24 \mathrm{~h}$ culture in control medium the labelled nuclei are also found in the syncytiotrophoblast. (c) After $24 \mathrm{~h}$ culture in the presence of caspase 8 inhibitors the labelled nuclei are still mostly within the cytotrophoblast layer and the syncytiotrophoblast nuclei are only rarely stained. (a-c): fluorescence and transmission image overlays. Bars: $10 \mu \mathrm{m}$

by active caspase 8 . Western blot analysis using the antibody M30 (recognizing a caspase-dependent cytokeratin 18 neoepitope) revealed that in the presence of peptide inhibitors against caspase 8, cleavage of cytokeratin 18 was significantly reduced (Figure $8 \mathrm{~b}$ ). Also, the quantification of M30 immunohistochemistry revealed a reduction of trophoblast apoptosis in explants cultured with caspase 8 inhibitors (Figure 7b).

To test whether the multilayered cytotrophoblast is a result of reduced fusion rather than of increased proliferation, Western blots with the proliferation marker anti-PCNA were performed. These blots did not show an increase of proliferation in the presence of peptide inhibitors against caspase 8 (Figure $8 \mathrm{c}$ ). Also, the quantification of Mib-1 immunohistochemistry did not reveal an increase in trophoblast proliferation after $24 \mathrm{~h}$ culture in the presence of peptide inhibitors against caspase 8 (Figure 7c).

\section{Discussion}

\section{Methodological approach}

In our first publication on interactions between apoptosis and syncytial fusion of villous trophoblast, we discussed the potential involvement of initiator caspases in syncytial fusion based on descriptive immunohistochemistry data. ${ }^{10}$ Additional biochemical analysis of caspase activities from isolated cytotrophoblast and syncytiotrophoblast revealed the activity of initiator caspase 8, but no activity of the effector caspases 3 and 6 in cytotrophoblast, while in syncytiotrophoblast all the three caspases were found to be active. ${ }^{12}$

The approach described here focuses on caspase 8 protein expression and caspase 8 protein activities in an in vitro model using villous explants. In this model, villous cytotrophoblast continues to proliferate and structural organization of the villous trophoblast layer stays intact for several days, ${ }^{32,33}$ even in the presence of antisense oligonucleotides. ${ }^{34}$ The explant model allows the observation of cytotrophoblast fusion in the living complex placental tissue. It is superior to the use of primary trophoblast cells, which upon isolation irreversibly leave the cell cycle and undergo apoptosis within a few days. Moreover, accidental admixtures of mononuclear syncytiotrophoblast fragments in the isolations of cytotrophoblast ${ }^{12,35}$ hinder the analysis of the specific effects of caspase inhibitors on cytotrophoblast.

Fluorescence-tagged oligonucleotides are known to bind to karyoskeletal elements of proliferative cells. ${ }^{36}$ In placental villi, they bind to cytotrophoblast rather than to syncytiotrophoblast nuclei. Using FITC-labelled random oligonucleotides as a nuclear stain enabled us to use these molecules as markers 
a

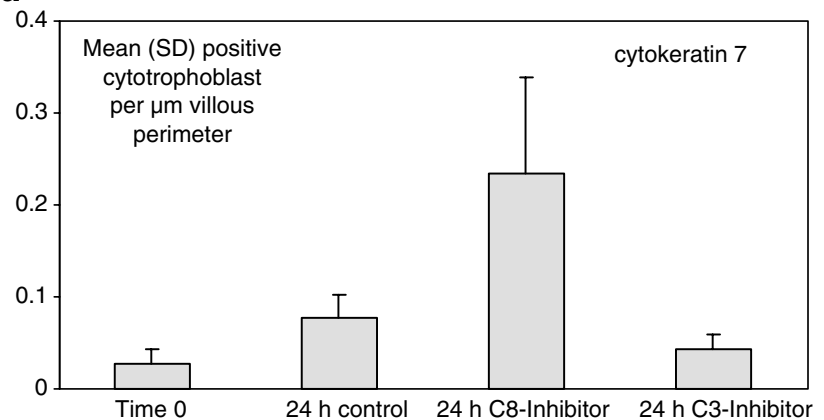

b

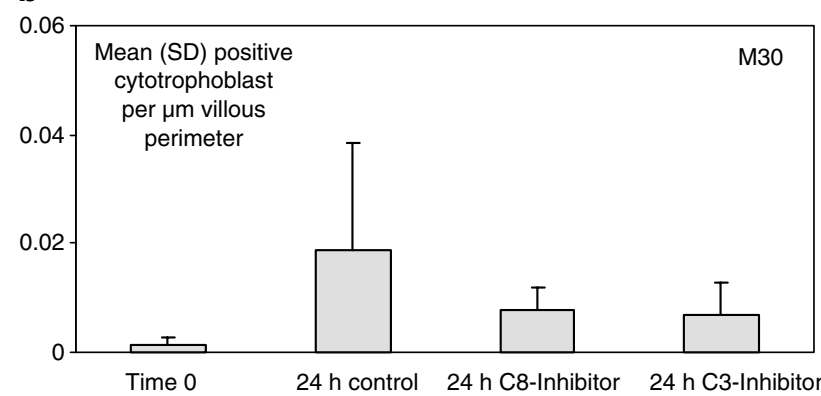

C

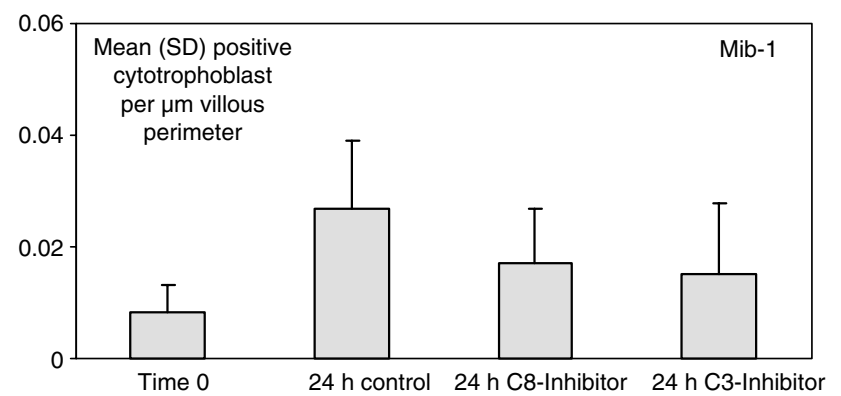

Figure 7 Quantification of cytotrophoblast staining using (a) anti-cytokeratin 7 (number of cells), (b) M30 (apoptosis) and (c) Mib-1 (proliferation) antibodies. The number of immune-positive cells per $\mu \mathrm{m}$ of villous perimeter was calculated from five placentas, analysing more than 100 villi per condition. In $(\mathbf{a}-\mathbf{c})$ there were statistically significant differences between the groups (ANOVA: $P<0.05$ ). In (a) significantly higher numbers of cytotrophoblast were found in the explants cultured with caspase 8 inhibitors (Bonferroni: C8-inhibitor vs control, $P<0.05$ ). $\operatorname{In}(\mathbf{b})$ and (c) there was a significant increase in apoptosis and proliferation from fresh tissue to explants cultured for $24 \mathrm{~h}$ in normal medium (Bonferroni: time $0 \mathrm{vs}$ control, $P<0.05$ ). Time 0 , fresh tissue prior to culture; $24 \mathrm{~h}$ control, explants cultured for $24 \mathrm{~h}$ in normal medium; C8-inhibitor, explants cultured for $24 \mathrm{~h}$ with caspase 8 inhibitors; C3-inhibitor, explants cultured for $24 \mathrm{~h}$ with caspase 3 inhibitors

for syncytial fusion. In the presence of peptide inhibitors against caspase 8 , syncytial fusion between the cytotrophoblast which was prestained with FITC-labelled random oligonucleotides and syncytiotrophoblast is mostly blocked, leaving the FITC-stained nuclei in the cytotrophoblast layer (see Figure 6).

We demonstrated effective inhibition of the caspase cascade within the trophoblast by analysing the degradation of an epithelium-specific protein, cytokeratin 18. During apoptosis of epithelial cells such as trophoblast, cytokeratin 18 is specifically cleaved by effector caspases, the activation

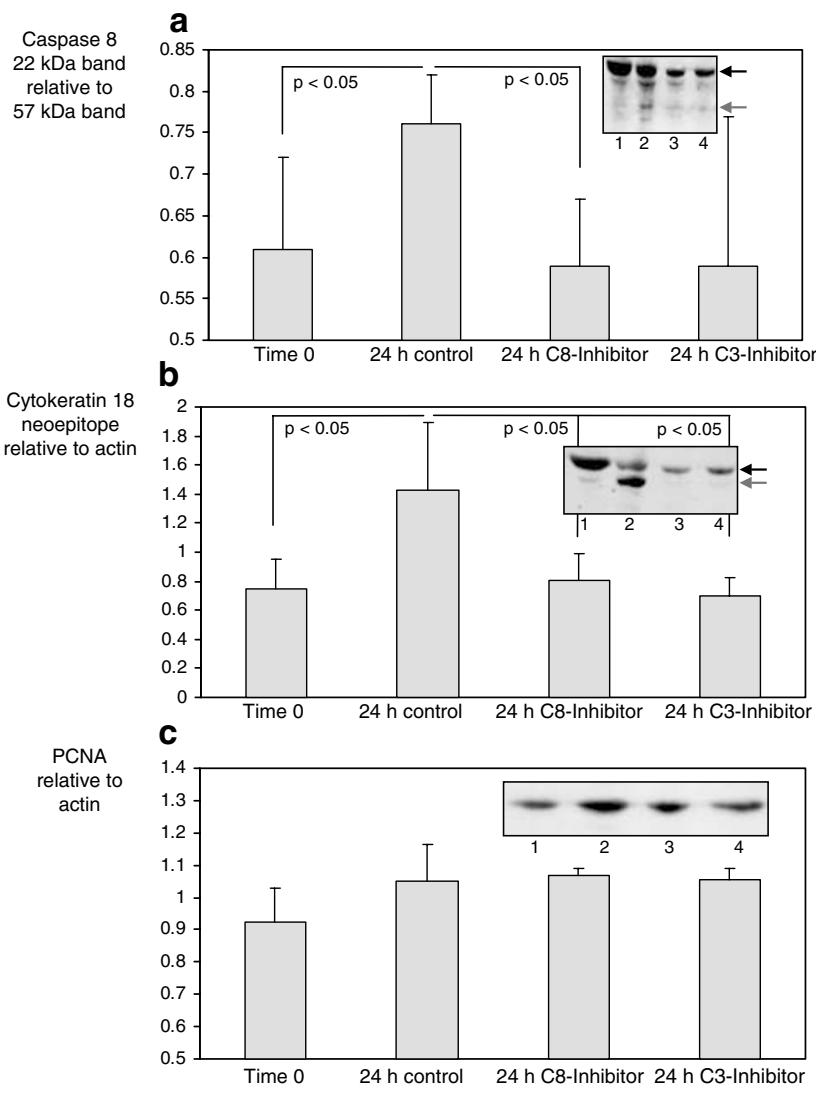

Figure 8 Quantifications of Western blots for (a) caspase 8, (b) cytokeratin 18 neoepitope formation (M30) and (c) PCNA. In all diagrams column 1 represents the tissue prior to culture (time 0; lane 1 in inserts), column 2 represents the tissue after $24 \mathrm{~h}$ culture in normal medium ( $24 \mathrm{~h}$ contr.; lane 2 in inserts), column 3 represents the tissue after $24 \mathrm{~h}$ culture in the presence of $1 \mu \mathrm{M}$ reversible caspase 8 inhibitor ( $24 \mathrm{~h}$ C8-inhibitor; lane 3 in inserts), and column 4 represents the tissue after $24 \mathrm{~h}$ culture in the presence of $1 \mu \mathrm{M}$ irreversible inhibitor of caspase 3 ( $24 \mathrm{~h}$ C3-inhibitor; lane 4 in inserts). M30 and PCNA were related to the house-keeping protein actin while the cleaved form of caspase $8(22 \mathrm{kDa})$ was related to the proform of caspase $8(57 \mathrm{kDa})$. In insert (a) the black arrow points to the inactive proform at $57 \mathrm{kDa}$ and the grey arrow points to the active form at $22 \mathrm{kDa}$. In insert (b) the black arrow points to uncleaved cytokeratin 18 and the grey arrow points to the cleaved form. In (a) significant changes were found as follows $(n=5)$ : time 0 vs $24 \mathrm{~h}$ control: $P<0.05 ; 24 \mathrm{~h}$ control vs $24 \mathrm{~h} \mathrm{C}$ inhibitor: $P<0.05$. In (b) significant changes were found as follows $(n=3)$ : time 0 vs $24 \mathrm{~h}$ control: $P<0.05 ; 24 \mathrm{~h}$ control vs $24 \mathrm{~h}$ C8-Inhibitor: $P<0.05 ; 24 \mathrm{~h}$ control vs C3-inhibitor: $P<0.05$. In (c) no significant differences could be obtained $(n=3)$

of which depends on the activities of initiator caspases such as caspase 8. The Western blot in Figure $8 \mathrm{~b}$ demonstrates that cleavage of cytokeratin 18 in the presence of caspase 8 inhibitors is nearly completely blocked, suggesting that the caspase activation cascade was interrupted upstream.

\section{Initiator caspases are required for syncytial fusion of trophoblast}

There is increasing evidence that caspases are not only key players in programmed cell death, but also have crucial roles in cellular differentiation. The hypothesis that apoptosis is involved in development is obvious for cells where differentiation events include extrusion of the nucleus and loss of 


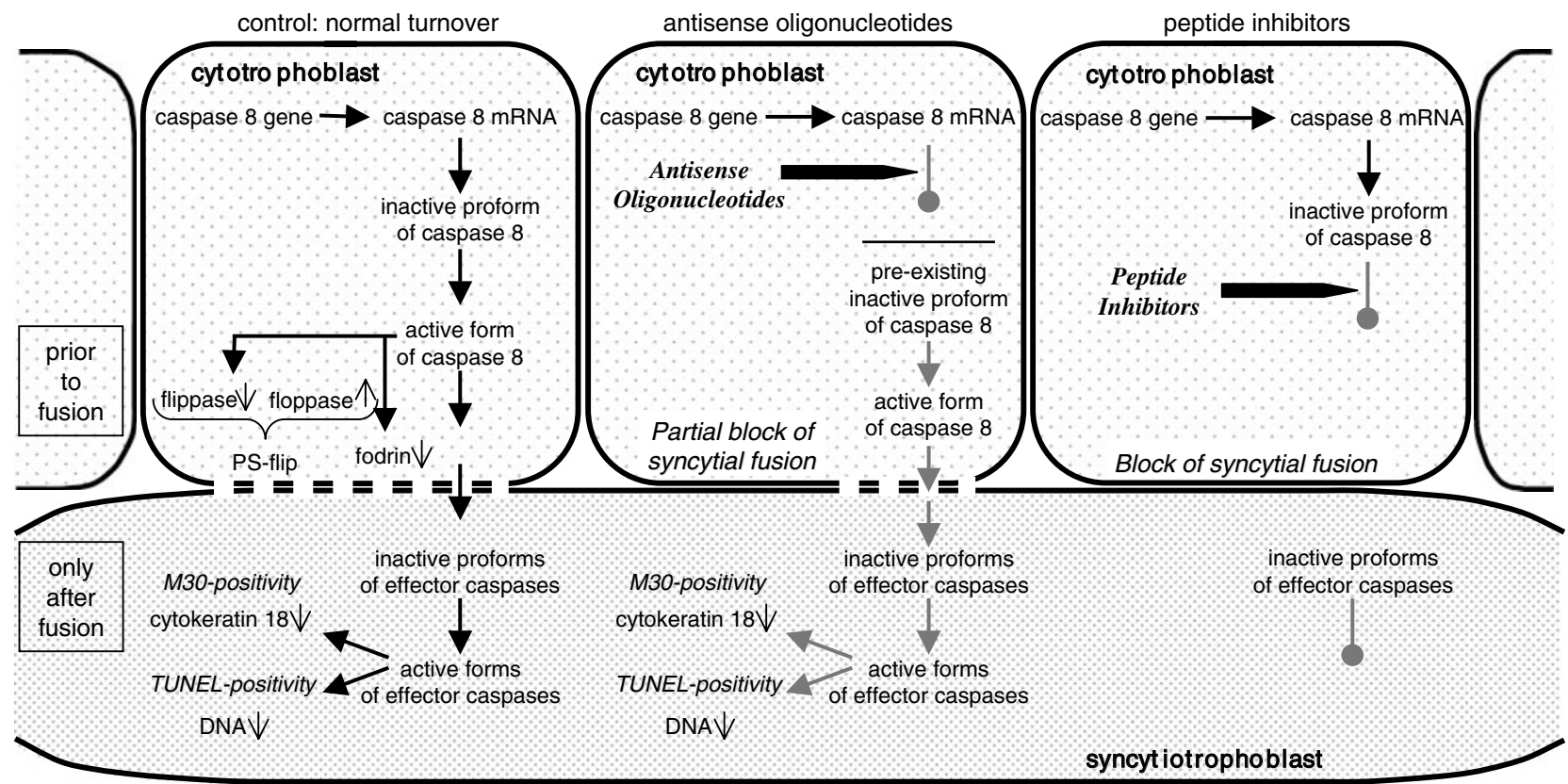

Figure 9 Scheme of the caspase 8 pathway from gene to active protein, as related to the process of syncytial fusion of villous trophoblast. Under normal conditions, the activity of caspase 8 leads to cytoskeletal and membrane changes of the cytotrophoblast, and subsequently to syncytial fusion with the syncytiotrophoblast. Inside the syncytiotrophoblast, the apoptosis cascade progresses, leading to activation of effector caspases and cleavage of the respective substrates. In the presence of antisense oligonucleotides against caspase 8 , the new protein expression of caspase 8 is blocked, but pre-existing proforms of caspase 8 may be activated, leading to still ongoing fusion. Only after a certain time the pool of pre-existing proforms is emptied, and only then the block of fusion occurs. In the presence of peptide inhibitors against caspase 8 , activation of the protease is blocked, leading to the stoppage of syncytial fusion. Further downstream in the syncytiotrophoblast, the apoptosis cascade is blocked due to missing activation of effector caspases

organelles, such as during erythrocyte maturation and lens fibre formation. Both types of cells achieve the degradation of their nucleus by the activation of effector caspases (caspase 3). ${ }^{14,15}$ Also, in stratified epithelia, caspase 3 has been found to be crucial for differentiation of keratinocytes. ${ }^{16}$ Caspase 14 , a new member of the effector caspase family, was found to be essential for differentiation in stratified ${ }^{17-19}$ as well as simple epithelia without any relation to apoptosis processes. ${ }^{37}$

The above-mentioned caspases belong to the subfamily of caspases with short prodomains ${ }^{38,39}$ that are widely considered as downstream effector caspases (caspases 3, 6, 7, 14). By contrast, caspases with long prodomains (e.g. caspases 2 , $8,9,10)$ serve as initiators by cleaving and activating the short-domain caspases.

There are only few data suggesting that the long prodomain caspases (initiator caspases) may also be involved in normal differentiation processes. During differentiation of secondary lens fibre cells from lens epithelium, caspase 9 activity was described to be involved in the downregulation of mitochondria during differentiation. ${ }^{40}$ Caspase 9 is a linker caspase that is activated during the type II pathway of the TNF superfamily members. After activation of the initiator caspases 8 or 10 , the signal is transferred to the mitochondria from which cytochrome $c$ is released, resulting in the activation of the apoptosome containing cytochrome $c$, Apaf- 1 and caspase 9 , which subsequently activate the effector caspases. ${ }^{41}$

Caspases 8 and 10 both contain two death effector domains that enable them to associate with death receptors. This feature places both initiator caspases most upstream in the apoptosis activation pathway. ${ }^{42,43}$ According to recent re- ports, they too may be involved in differentiation processes. However, different from those differentiation processes involving effector caspases (see above), differentiation linked to these early initiator caspases does not necessarily involve the obvious characteristics of apoptosis such as extrusion of nuclei. Alternative splicing of caspase 8 mRNA was found during differentiation of human leukocytes, ${ }^{44}$ and maturation of monocytes was shown to involve caspase 8 activation. ${ }^{45}$ The same group described that blockage of caspase 8 activity with the peptide inhibitor z-IETD-fmk resulted in a significant numerical reduction of maturated monocytes.

Villous cytotrophoblast cells seem to employ a related molecular machinery for differentiation and syncytial fusion with the syncytiotrophoblast (Figure 9). Also in this system, caspase 8 becomes activated prior to syncytial fusion, and signs of its enzymatic activity become evident; ${ }^{12,46}$ moreover, antisense inhibition of its protein expression partially (Figure 9), and peptide inhibition of its activity (by z-IETDfmk) more or less completely, blocks differentiation and stops syncytial fusion (Figure 9).

Accumulation of cytotrophoblast in tandem with a stable rate of proliferation provides clear evidence for considerable reduction or even complete absence of syncytial fusion. Also, the expression of the organic anion transporter hOAT- $4^{29}$ normally expressed in the syncytiotrophoblast supports this notion. Following blockage of caspase 8 , it is restricted to the cytotrophoblast and missing in the syncytiotrophoblast. Prerequisites for syncytial fusion in general are reorganization of the cytoskeleton and plasma membrane lipids. This can be visualized by the degradation of alpha-fodrin and the flip of 
phosphatidylserine from the inner to the outer leaflet of the plasma membrane. ${ }^{22,23}$ Both events take place in highly differentiated cytotrophoblast, ${ }^{12,22,23}$ and cleavage of alphafodrin $^{21,47}$ as well as the externalization of phosphatidylserine $^{48,49}$ are known targets of caspase 8 activity.

The changes in membrane stability (fodrin cleavage) and the rearrangement of charges within the membrane (PS-flip) provide the physicochemical properties required for syncytial fusion in general. They provide the prerequisites for fusion, while other regulatory factors such as the fusogenic proteins of the ADAM family (a disintegrin and a metalloproteinase domain ${ }^{50}$ ) or virus-cell fusion proteins such as the HIV-Env protein $^{51}$ are involved in the fusion process directly.

Finally, it should be pointed out that caspases may not be involved in the preparation of syncytial fusion in all syncytial tissues. We have recently described a series of striking similarities between syncytial fusion in both trophoblast and skeletal muscle. ${ }^{52}$. However, in the latter tissue, calpains and not caspases seem to be involved in the preparation of syncytial fusion of myoblasts generating the skeletal myotubes. ${ }^{53}$. Calpains are proteases with functional similarities to caspases. ${ }^{54}$ Interestingly, they were also found to be involved in senescence of red blood cells, a prolonged apoptotic event. $^{55}$

\section{Conclusions}

In summary, our data extend earlier findings that expression and activity of caspase 8 is required for differentiation including syncytial fusion of the villous cytotrophoblast.

Inhibition of caspase 8 activity by peptide inhibitors:

- blocks syncytial fusion of trophoblast measured by transfer of labelled nuclei from the cytotrophoblast to the syncytiotrophoblast layer;

- retains hOAT-4 inside the cytotrophoblast, a transporter normally expressed in cytotrophoblast and transferred into the syncytiotrophoblast by syncytial fusion;

- blocks the activation of effector caspases downstream the apoptosis cascade (Figure 9).

Inhibition of caspase 8 protein expression by antisense oligonucleotides:

- reduces the amount of caspase 8 protein in the explants;

- reduces but not fully blocks all of the above processes, due to the presence of preexisting caspase 8 proteins already expressed prior to antisense inhibition (Figure 9).

Thus, blockage of caspase 8 expression and activity leads to blockade of syncytial fusion, thereby preventing progression of the apoptosis cascade in syncytiotrophoblast. Since progression of the apoptosis cascade in syncytiotrophoblast depends on continuous fusion throughout pregnancy, this perturbation of trophoblast turnover may lead to the incomplete execution of the apoptosis program and subsequent degeneration of syncytiotrophoblast via necrosis (aponecro$\left.\mathrm{sis}^{56}\right)$. Further studies are in progress to assess the roles of calpains and other related proteases in the differentiation of cytotrophoblast, and the subsequent consequences for the turnover of the syncytiotrophoblast.

\section{Materials and Methods}

\section{Placental explant culture}

Placental villi were obtained with ethical approval from the local ethics committee from late first trimester legal terminations of pregnancy dated by ultrasound (8-12 postmenstrual weeks), and from third trimester normal deliveries (38-40 weeks of gestation). Placental villous tissues were dissected under sterile conditions in ice-cold PBS. Small clusters of placental villi (40-50 mg wet weight) were placed in 24-well plates in DMEM/F12 (Gibco, Grand Island, NY, USA), supplemented with $10 \%$ FCS, $100 \mu \mathrm{g} / \mathrm{ml}$ streptomycin, $100 \mathrm{U} / \mathrm{ml}$ penicillin and $0.25 \mu \mathrm{g} / \mathrm{ml}$ ascorbic acid, pH 7.4. Villous explants were placed at $37^{\circ} \mathrm{C}$ in an atmosphere of $6 \%$ $\mathrm{O}_{2}(39.8 \pm 1.0 \mathrm{mmHg})$ in balance $\mathrm{N}_{2} / 5 \% \mathrm{CO}_{2}$ for up to $120 \mathrm{~h}$. Explants from 15 placentas of both gestation periods were cultured. Experiments were performed at least six times for each time point and culture condition. Results were similar in explants from both gestational ages. Due to the higher number of cytotrophoblast per villous cross-section in first trimester tissues, the results focus on these tissues.

\section{Antisense oligonucleotides and caspase inhibitors}

Villous explants were incubated with two different antisense oligonucleotides against caspase 8 and one antisense oligonucleotide against caspase 3. The specific phosphorothioate oligonucleotides and their controls have been designed and manufactured by Biognostik (Göttingen, Germany). The antisense oligonucleotides were the reverse of target sequences within the coding region of caspases 3 and 8 , as described in Fernandes-Alnemri et al. ${ }^{57}$ No cross homologies were found in the GeneBank database.

Sequences of caspase 8 antisense oligonucleotides were (1) GAG GCC AGA TCT TCA C and (2) CAT CGC TCT CTC AGG. Sequences of caspase 8 control oligonucleotides were (1) GCT CTA TGA CTC CCA G and (2) CGT CCC TAT ACG ACC. The sequence of caspase 3 antisense oligonucleotide was CCC TCT GAA AAA GTT TGT TAT and that of caspase 3 control oligonucleotide was GGA CTA CTA CAC TAG ACT AC.

For control purposes, experiments were carried out in parallel in the presence of antisense oligonucleotides against bcl-2 and syncytin. The results obtained with the caspase 8 antisense oligonucleotides were unique to these probes, and could not be reproduced using any other probe (data not shown for bcl-2 and syncytin).

The explants were incubated for 24,48 or $120 \mathrm{~h}$ in the presence of 2 or $4 \mu \mathrm{M}$ antisense oligonucleotides. Further control incubations were performed using no oligonucleotides or using FITC-labelled or unlabelled unspecific oligonucleotides. These oligonucleotides did not show any cross homologies to other sequences in the GeneBank database. Explants were incubated for $1 \mathrm{~h}$ with $2 \mu \mathrm{M}$ FITC-labelled random oligonucleotides, to test whether the oligonucleotides enter the explant tissues. After culture, the FITC-labelled villi were visualized using an inverted fluorescence microscope (DM-IL, Leica, Germany) or a confocal laser-scanning microscope (TCS-NT, Leica, Germany).

Villous explants were incubated with two different cell-permeable peptide inhibitors against caspase 8, a reversible inhibitor (IETD-CHO; Calbiochem, Bad Soden, Germany) and an irreversible inhibitor (z-IETD$\mathrm{fmk}$, Calbiochem). The explants were incubated for up to $48 \mathrm{~h}$ in $0.1,0.5,1$ and $5 \mu \mathrm{M}$ peptide inhibitors. Culture conditions were as described above. Control incubations were performed using the same concentrations of peptide inhibitors against caspase 3 (DEVD-CHO and z-DEVD-fmk; Calbiochem), or using no inhibitor at all. 
To visualize the effect of caspase 8 inhibitors on fusion and the transfer of staining from the cytotrophoblast to the syncytiotrophoblast, we used the following approach. Villous explants from first trimester placentas were incubated for $90 \mathrm{~min}$ with $2 \mu \mathrm{M}$ FITC-labelled random oligonucleotides, washed and (a) visualized directly, (b) cultured for $24 \mathrm{~h}$ without inhibitors and then visualized and (c) cultured for $24 \mathrm{~h}$ in the presence of caspase 8 inhibitors (IETD-CHO) and then visualized using a confocal laser-scanning microscope.

\section{Immunohistochemistry}

Explants were fixed for $12 \mathrm{~h}$ in fresh neutral-buffered $4 \%$ paraformaldehyde and paraffin-embedded. Serial $5 \mu \mathrm{m}$ sections were cut and every fifth section was stained with haematoxylin and eosin. Intervening sections were rehydrated prior to peroxidase immunohistochemistry. The following primary antibodies (dilution/clone; source) were employed for $1 \mathrm{~h}$ at room temperature to assess trophoblast turnover as recently described: ${ }^{46} \mathrm{Mib}-1$ (1:20; Dianova, Hamburg, Germany), anti-hOAT-4 (1:50/rabbit polyclonal; Alpha Diagnostics, San Antonio, TX, USA), anti-cytokeratin 7 (1:200/M7018; Dako, Hamburg, Germany) and anti-cytokeratin 18 neoepitope (1:50/M30; Roche, Mannheim, Germany). For immunohistochemistry with the $\mathrm{M} 30$ antibody ${ }^{58}$ and the antibody against hOAT-4, a microwave pretreatment was performed. Binding of species-specific biotinylated secondary antibodies was visualized with AEC. Sections were viewed and photographed using an interference-contrast microscope (Axiophot, Zeiss, Germany).

\section{Quantification}

Sections stained for cytokeratin 7 (number of cytotrophoblasts), M30 (trophoblast apoptosis) and Mib-1 (proliferation) were evaluated using an inverted microscope (DM-IL, Leica, Germany). The circumference of each villus assessed was measured using the DISKUS 4.30.7 programme. Sections were taken from fresh villous tissue prior to culture, explants cultured for $24 \mathrm{~h}$ in normal medium, explants cultured for $24 \mathrm{~h}$ in the presence of peptide inhibitors against caspase 3 , and explants cultured for $24 \mathrm{~h}$ in the presence of peptide inhibitors against caspase 8. Five placentas (each with fresh tissue and the three different explant culture conditions) were analysed with more than 100 villi counted per condition. The data were analysed as the number of immune-positive cytotrophoblast cells per $\mu \mathrm{m}$ of villous perimeter. Statistical analyses were carried out by calculating mean and S.D. for each group and each investigated variable. Comparisons between groups were carried out using one-way ANOVA and post hoc Bonferroni's multiple comparison tests. Statistical significance was established at $P<0.05$.

\section{Western blotting}

Protein was extracted from explants (pooling six explants for each condition, approx. $300 \mathrm{mg}$ ) using PBS and Complete Mini proteinase inhibitor cocktail (Roche, Germany) as extraction buffer. Proteins concentration was estimated by Bradford test at $\mathrm{OD}_{595}$. Proteins $(100 \mu \mathrm{g})$ were size separated by $10 \%$ SDS-PAGE, transferred to a nylon membrane, blocked with TBS with $5 \%$ fat-free milk for $1 \mathrm{~h}$, rinsed two times in TBS with $0.05 \%$ Tween 20 , and incubated with primary antibodies (clone, company; dilution) anti cytokeratin 18 neoepitope (M30, Roche; 1:500), anti-caspase 8 (8CSP03, Dianova; 1:500), anti-PCNA (CBL407, Cymbus Biotechnoloy; 1:500), anti-actin (AC40, Sigma; 1:1000) and anti-vimentin (V9, Dako; $1: 500)$ at $4^{\circ} \mathrm{C}$ for $24 \mathrm{~h}$. Membranes were washed twice with TBS containing $0.05 \%$ Tween 20 , and incubated with anti- mouse secondary antibodies conjugated to alkaline phosphatase ( $1: 25000$; Jackson Laboratories) for $1 \mathrm{~h}$. The membranes were washed as described above, and incubated with Immune-Star chemiluminescence (Bio-Rad) and used to expose X-ray films (Kodak).

\section{Acknowledgements}

The excellent technical assistance of Uta Zahn is gratefully acknowledged. $\mathrm{PK}$ and $\mathrm{BH}$ are funded by the Rockefeller Foundation, Grants No. RF96020\#76 and RF99021\#114.

\section{References}

1. Benirschke $\mathrm{K}$ and Kaufmann $\mathrm{P}$ (2000) Pathology of the human placenta 4th edn (New York: Springer)

2. Pennica D, Nedwin GE, Hayflick JS, Seeburg PH, Derynck R, Palladino MA, Kohr WJ, Aggarwal BB and Goeddel DV (1984) Human tumour necrosis factor: precursor structure, expression and homology to lymphotoxin. Nature 312: 724-729

3. Yonehara S, Ishii A and Yonehara M (1989) A cell-killing monoclonal antibody (anti-Fas) to a cell surface antigen co-downregulated with the receptor of tumor necrosis factor. J. Exp. Med. 169: 1747-1756

4. Trauth BC, Klas C, Peters AM, Matzku S, Moller P, Falk W, Debatin KM and Krammer PH (1989) Monoclonal antibody-mediated tumor regression by induction of apoptosis. Science 245: 301-305

5. Kischkel FC, Hellbardt S, Behrmann I, Germer M, Pawlita M, Krammer PH and Peter ME (1995) Cytotoxicity-dependent APO-1 (Fas/CD95)-associated proteins form a death-inducing signaling complex (DISC) with the receptor. EMBO J. 14: $5579-5588$

6. Lavrik I, Krueger A, Schmitz I, Baumann S, Weyd H, Krammer PH and Kirchhoff $S$ (2003) The active caspase-8 heterotetramer is formed at the CD95 DISC. Cell Death Differ. 10: 144-145

7. Yui J, Garcia-Lloret M, Wegmann TG and Guilbert LJ (1994) Cytotoxicity of tumour necrosis factor-alpha and gamma-interferon against primary human placental trophoblasts. Placenta 15: 819-835

8. Phillips TA, Ni J and Hunt JS (2001) Death-inducing tumour necrosis factor (TNF) superfamily ligands and receptors are transcribed in human placentae, cytotrophoblasts, placental macrophages and placental cell lines. Placenta 22: 663-672

9. LeBrun DP, Warnke RA and Cleary ML (1993) Expression of bcl-2 in fetal tissues suggests a role in morphogenesis. Am. J. Pathol. 142: 743-753

10. Huppertz B, Frank HG, Kingdom JCP, Reister F and Kaufmann P (1998) Villous cytotrophoblast regulation of the syncytial apoptotic cascade in the human placenta. Histochem. Cell Biol. 110: 495-508

11. Suzuki A, Umezawa A, Sano M, Nozawa S and Hata J (2000) Involvement of EAT/mcl-1, a bcl-2 related gene, in the apoptotic mechanisms underlying human placental development and maintenance. Placenta 21: 177-183

12. Huppertz B, Frank HG, Reister F, Kingdom J, Korr H and Kaufmann P (1999) Apoptosis cascade progresses during turnover of human trophoblast: analysis of villous cytotrophoblast and syncytial fragments in vitro. Lab. Invest. 79: 1687-1702

13. Yusuf K, Smith SD, Sadovsky $Y$ and Nelson DM (2002) Trophoblast differentiation modulates the activity of caspases in primary cultures of term human trophoblasts. Pediatr. Res. 52: 411-415

14. Ishizaki Y, Jacobson MD and Raff MC (1998) A role for caspases in lens fiber differentiation. J. Cell Biol. 140: 153-158

15. Morioka K, Tone S, Mukaida M and Takano-Ohmuro H (1998) The apoptotic and nonapoptotic nature of the terminal differentiation of erythroid cells. Exp. Cell Res. 240: 206-217

16. Weil M, Raff MC and Braga VM (1999) Caspase activation in the terminal differentiation of human epidermal keratinocytes. Curr. Biol. 9: 361-364

17. Eckhart L, Declercq W, Ban J, Rendl M, Lengauer B, Mayer C, Lippens S, Vandenabeele $P$ and Tschachler E (2000) Terminal differentiation of human keratinocytes and stratum corneum formation is associated with caspase-14 activation. J. Invest. Dermatol. 115: 1148-1151 
18. Lippens S, Kockx M, Knaapen M, Mortier L, Polakowska R, Verheyen A, Garmyn M, Zwijsen A, Formstecher P, Huylebroeck D, Vandenabeele P and Declercq W (2000) Epidermal differentiation does not involve the pro-apoptotic executioner caspases, but is associated with caspase-14 induction and processing. Cell Death Differ. 7: 1218-1224

19. Chien AJ, Presland RB and Kuechle MK (2002) Processing of native caspase14 occurs at an atypical cleavage site in normal epidermal differentiation. Biochem. Biophys. Res. Commun. 296: 911-917

20. Martin SJ, O'Brien GA, Nishioka WK, McGahon AJ, Mahboubi A, Saido TC and Green DR (1995) Proteolysis of fodrin (non-erythroid spectrin) during apoptosis. J. Biol. Chem. 270: 6425-6428

21. Greidinger EL, Miller DK, Yamin TT, Casciola-Rosen L and Rosen A (1996) Sequential activation of three distinct ICE-like activities in Fas-ligated Jurkat cells. FEBS Lett. 390: 299-303

22. Adler RR, Ng AK and Rote NS (1995) Monoclonal antiphosphatidylserine antibody inhibits intercellular fusion of the choriocarcinoma line, JAR. Biol. Reprod. 53: 905-910

23. Vogt E, Ng AK and Rote NS (1997) Antiphosphatidylserine antibody removes annexin- $V$ and facilitates the binding of prothrombin at the surface of a choriocarcinoma model of trophoblast differentiation. Am. J. Obstet. Gynecol. 177: 964-972

24. Rohn TT, Rissman RA, Davis MC, Kim YE, Cotman CW and Head E (2002) Caspase- 9 activation and caspase cleavage of tau in the Alzheimer's disease brain. Neurobiol. Dis. 11: 341-354

25. Issa Y, Watts DC, Duxbury AJ, Brunton PA, Watson MB and Waters CM (2003) Mercuric chloride: toxicity and apoptosis in a human oligodendroglial cell line MO3.13. Biomaterials 24: $981-987$

26. Vanden Hoek TL, Qin Y, Wojcik K, Li CQ, Shao ZH, Anderson T, Becker LB and Hamann KJ (2003) Reperfusion, not simulated ischemia, initiates intrinsic apoptosis injury in chick cardiomyocytes. Am. J. Physiol. Heart Circ. Physiol. 284: $\mathrm{H} 141-\mathrm{H} 150$

27. McArthur $C$, Wang $Y$, Veno $P$, Zhang $J$ and Fiorella $R$ (2002) Intracellular trafficking and surface expression of SS-A (Ro), SS-B (La), poly(ADP-ribose) polymerase and alpha-fodrin autoantigens during apoptosis in human salivary gland cells induced by tumour necrosis factor-alpha. Arch. Oral Biol. 47: 443448

28. Berg CP, Engels IH, Rothbart A, Lauber K, Renz A, Schlosser SF, SchulzeOsthoff $K$ and Wesselborg $S$ (2001) Human mature red blood cells express caspase-3 and caspase-8, but are devoid of mitochondrial regulators of apoptosis. Cell Death Differ. 8: 1197-1206

29. Ugele R, St.Pierre MV, Pihusch M, Bahn A and Hantschmann P (2003) Characterization and identification of steroid sulphate transporters of human placenta. Am. J. Physiol. Endocrinol. Metab. 284: E390-E398

30. Caulin C, Salvesen GS and Oshima RG (1997) Caspase cleavage of keratin 18 and reorganization of intermediate filaments during epithelial cell apoptosis. J. Cell Biol. 138: 1379-1394

31. MacFarlane M, Merrison W, Dinsdale D and Cohen GM (2000) Active caspases and cleaved cytokeratins are sequestered into cytoplasmic inclusions in TRAILinduced apoptosis. J. Cell Biol. 148: 1239-1254

32. Castellucci M, Kaufmann $P$ and Bischof $P(1990)$ Extracellular matrix influences hormone and protein production by human chorionic villi. Cell Tissue Res. 262: $135-142$

33. Begum-Hasan J, Senterman M, Gillett $P$, LaPlante Branchaud $C$ and Murphy BE (1993) Effect of maternal serum on viability and function of early human placental explants. In Vitro Cell Dev. Biol. Anim. 29A: 505-511

34. Lappas M, Munns MJ, King RG and Rice GE (2001) Antisense oligonucleotide inhibition of type II phospholipase A2 expression, release and activity in vitro. Placenta 22: 418-424

35. Guilbert LJ, Winkler-Lowen B, Sherburne R, Rote NS, Li H and Morrish DW (2002) Preparation and functional characterization of villous cytotrophoblasts free of syncytial fragments. Placenta 23: 175-183

36. Shoeman RL, Hartig R, Huang Y, Grub S and Traub P (1997) Fluorescence microscopic comparison of the binding of phosphodiester and phosphorothioate (antisense) oligodeoxyribonucleotides to subcellular structures, including intermediate filaments, the endoplasmic reticulum, and the nuclear interior. Antisense Nucleic Acid Drug Dev. 7: 291-308
37. Pistritto G, Jost M, Srinivasula SM, Baffa R, Poyet JL, Kari C, Lazebnik Y, Rodeck $U$ and Alnemri ES (2002) Expression and transcriptional regulation of caspase-14 in simple and complex epithelia. Cell Death Differ. 9: 995-1006

38. Nicholson DW and Thornberry NA (1997) Caspases: killer proteases. Trends Biochem. Sci. 22: 299-306

39. Salvesen GS and Dixit VM (1997) Caspases: intracellular signaling by proteolysis. Cell 91: 443-446

40. Sanders EJ and Parker E (2002) The role of mitochondria, cytochrome $c$ and caspase-9 in embryonic lens fibre cell denucleation. J. Anat. 201: 121-135

41. Zou H, Li Y, Liu X and Wang X (1999) An APAF-1-cytochrome $c$ multimeric complex is a functional apoptosome that activates procaspase-9. J. Biol. Chem. 274: 11549-11556

42. Fernandes-Alnemri T, Armstrong RC, Krebs J, Srinivasula SM, Wang L, Bullrich F, Fritz LC, Trapani JA, Tomaselli KJ, Litwack G and Alnemri ES (1996) In vitro activation of CPP32 and Mch3 by Mch4, a novel human apoptotic cysteine protease containing two FADD-like domains. Proc. Natl. Acad. Sci. USA 93: 7464-7469

43. Muzio M, Chinnaiyan AM, Kischkel FC, O'Rourke K, Shevchenko A, Ni J, Scaffidi C, Bretz JD, Zhang M, Gentz R, Mann M, Krammer PH, Peter ME and Dixit VM (1996) FLICE, a novel FADD-homologous ICE/CED-3-like protease, is recruited to the CD95 (Fas/APO-1) death-inducing signaling complex. Cell 85 : 817-827

44. Eckhart L, Henry M, Santos-Beneit AM, Schmitz I, Krueger A, Fischer H, Bach J, Ban J, Kirchhoff S, Krammer PH, Mollinedo F and Tschachler E (2001) Alternative splicing of caspase-8 mRNA during differentiation of human leukocytes. Biochem. Biophys. Res. Commun. 289: 777-781

45. Secchiero P, Gonelli A, Mirandola P, Melloni E, Zamai L, Celeghini C, Milani D and Zauli G (2002) Tumor necrosis factor-related apoptosis-inducing ligand induces monocytic maturation of leukemic and normal myeloid precursors through a caspase-dependent pathway. Blood 100: 2421-2429

46. Huppertz B, Frank HG and Kaufmann P (1999) The apoptosis cascade morphological and immunohistochemical methods for its visualization. Anat. Embryol. 200: 1-18

47. Jaenicke RU, Ng P, Sprengart ML and Porter AG (1998) Caspase-3 is required for alpha-fodrin cleavage but dispensable for cleavage of other death substrates in apoptosis. J. Biol. Chem. 273: 15540-15545

48. Chen X, Wan Y, Bai Q, Zhang W and Zhu H (2002) Sodium salicylate-triggered apoptosis in $\mathrm{HL}-60$ cells depends on caspase-8 activation. Int. J. Hematol. 75 : $407-411$

49. Ferraro-Peyret C, Quemeneur L, Flacher M, Revillard JP and Genestier L (2002) Caspase-independent phosphatidylserine exposure during apoptosis of primary T lymphocytes. J. Immunol. 169: 4805-4810

50. Wolfsberg TG and White JM (1996) ADAMs in fertilization and development Dev. Biol. 180: 389-401

51. LaBranche CC, Galasso G, Moore JP, Bolognesi DP, Hirsch MS and Hammer SM (2001) HIV fusion and its inhibition. Antiviral Res. 50: 95-115

52. Huppertz B, Tews DS and Kaufmann P (2001) Apoptosis and syncytial fusion in human placental trophoblast and skeletal muscle. Int. Rev. Cytol. 205: 215-253

53. Dedieu S, Dourdin N, Dargelos E, Poussard S, Veschambre P, Cottin P and Brustis JJ (2002) Calpain and myogenesis: development of a convenient cell culture model. Biol. Cell 94: 65-76

54. Wang KK (2000) Calpain and caspase: can you tell the difference? Trends Neurosci. 23: 20-26

55. Berg CP, Engels IH, Rothbart A, Lauber K, Renz A, Schlosser SF, SchulzeOsthoff $K$ and Wesselborg $S$ (2001) Human mature red blood cells express caspase-3 and caspase-8, but are devoid of mitochondrial regulators of apoptosis. Cell Death Differ. 8: 1197-1206

56. Formigli L, Papucci L, Tani A, Schiavone N, Tempestini A, Orlandini GE, Capaccioli S and Orlandini SZ (2000) Aponecrosis: morphological and biochemical exploration of a syncretic process of cell death sharing apoptosis and necrosis. J. Cell Physiol. 182: 41-49

57. Fernandes-Alnemri T, Litwack G and Alnemri ES (1994) CPP32, a nove human apoptotic protein with homology to Caenorhabditis elegans cell death protein CED-3 and mammalian interleukin-1-beta-converting enzyme. J. Biol. Chem. 269: 30761-30764

58. Kadyrov M, Kaufmann P and Huppertz B (2001) Expression of a cytokeratin 18 neo-epitope is a specific marker for trophoblast apoptosis in human placenta. Placenta 22: 44-48 